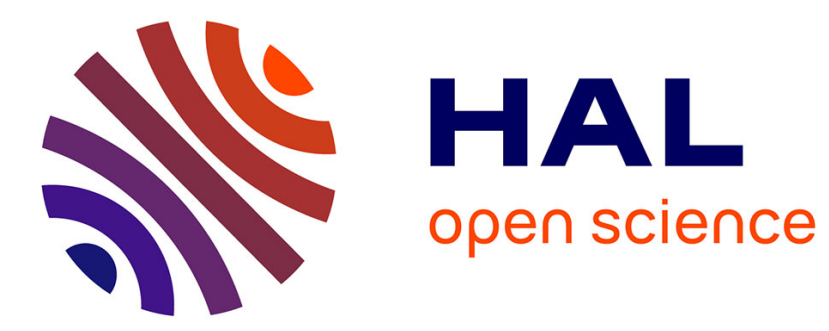

\title{
PROPERTIES OF CALCIUM FLUORIDE MONOCRYSTALS IN THE ULTRA LOW FREQUENCY RANGE, SPACE CHARGE AND IMPURITY EFFECTS
}

M. Maitrot, R. Madru

\section{To cite this version:}

M. Maitrot, R. Madru. PROPERTIES OF CALCIUM FLUORIDE MONOCRYSTALS IN THE ULTRA LOW FREQUENCY RANGE, SPACE CHARGE AND IMPURITY EFFECTS. Journal de Physique Colloques, 1976, 37 (C7), pp.C7-349-C7-352. 10.1051/jphyscol:1976780 • jpa-00216940

\author{
HAL Id: jpa-00216940 \\ https://hal.science/jpa-00216940
}

Submitted on 1 Jan 1976

HAL is a multi-disciplinary open access archive for the deposit and dissemination of scientific research documents, whether they are published or not. The documents may come from teaching and research institutions in France or abroad, or from public or private research centers.
L'archive ouverte pluridisciplinaire HAL, est destinée au dépôt et à la diffusion de documents scientifiques de niveau recherche, publiés ou non, émanant des établissements d'enseignement et de recherche français ou étrangers, des laboratoires publics ou privés. 


\title{
PROPERTIES OF CALCIUM FLUORIDE MONOCRYSTALS IN THE ULTRA LOW FREQUENCY RANGE, SPACE CHARGE AND IMPURITY EFFECTS
}

\author{
M. MAITROT and R. MADRU \\ Laboratoire de Physique Electronique 2, Université Cl.-Bernard, Lyon 1, \\ 43, boulevard du 11-novembre-1918, 69621 Villeurbanne, France
}

\begin{abstract}
Résumé. - Les propriétés diélectriques de plusieurs monocristaux de Fluorure de Calcium ont été étudiées dans un grand intervalle de température au moyen de plusieurs méthodes expérimentales complémentaires. Nous avons enregistré la composante en phase et la composante en opposition de phase du courant alternatif en très basse fréquence, ainsi que la répartition de potentiel par la méthode du fil vibrant. Enfin d'autres méthodes (effet électret) peuvent aussi être utilisées. Nous avons obtenu de nombreux renseignements sur les effets de conduction et les effets interfaciaux, et nous avons pu distinguer les effets en volume et en surface. Deux, et plus souvent trois relaxations apparaissent dans les monocristaux étudiés. Les deux premières sont dues aux impuretés, et la troisième est un phénomène de diffusion de Warburg par dessus une barrière superficielle. Ce phénomène de diffusion dépend de la tension continue et de l'atmosphère.

On discute la liaison entre relaxations dues aux impuretés et effet électret.
\end{abstract}

\begin{abstract}
Dielectric properties of some monocrystalline $\mathrm{CaF}_{2}$ samples were studied in a large temperature range, with several experimental methods : Ultra low frequency Ac recording apparatus, potential distribution vibrating wire method and electret recording where used. Much information was obtained on conduction and interfacial effects, bulk and electrode relaxations being differentiated. Two or three relaxations are often observed : the first two are impurity effects, but the third is a Warburg diffusion above the surface barrier, with intrinsic activation energy. The Warburg phenomenon appears as an electrode effect in potential distribution measurements and it depends on voltage and surrounding atmosphere.
\end{abstract}

Among the impurity effects, one finds a $1.25-1.30 \mathrm{eV}$ relaxation in all the samples - this relaxation is linked to an electret previously studied.

1. Introduction. - Some papers about relaxations $[1,2]$ and electret effect [3] in $\mathrm{CaF}_{2}$ monocrystals were recently published, dealing with low temperature relaxations $\left(0<T<300^{\circ} \mathrm{C}\right)$ and high temperature relaxations $\left(T>300^{\circ} \mathrm{C}\right)$.

In the low temperature range, the relaxations are linked to bulk conduction and are impurity effects. Nevertheless, these relaxations are of two kinds: independent on DC superimposed voltage (and likely Maxwell Wagner relaxations) or dependent on this superposed voltage (Schottky relaxations linked to electret effect).

In the high temperature range $\left(T>300^{\circ} \mathrm{C}\right) \mathrm{U}$. L. F. (ultra low frequency) relaxation is a Warburg effect, and this relaxation can be easily studied in a very large temperature range by admittance plots. By modifying the applied voltage and the surrounding atmosphere, this intrinsic effect varies. The conventional space charge theory [4] with one kind of partly blocked carriers does not agree with our results, because the band bending is not accounted for. The high temperature effect is a diffusion effect above a surface barrier.
2. Experimental. - The experimental apparatus was described elsewhere [2]. For U. L. F. measurements, we used a Keithley electrometer and recorded the in phase and $90^{\circ}$ out of phase current components. The voltage distribution in the sample was recorded by a vibrating wire apparatus [2]. The wire was very fine $(20 \mu)$ so it was possible to record the potential on the edge of $1 \mathrm{~mm}$ thick samples.

Some monocrystals were supplied by SOREM with a measured cationic impurity content- and some from Harshaw and Quartz and Silice. The relaxations were very reproducible in each crystal, when $\mathrm{Au}$ electrodes were evaporated on the surfaces, and when the pressure was about $10^{-6}$ torr.

3. Results. - We have only studied the large relaxations (with $\operatorname{tg} \delta \geqslant 1$ ) with these high values of $\operatorname{tg} \delta$, we cannot obtain dipolar relaxations, but only free charges relaxations.

3.1 Low TEMPERATURE RANGE $0-300^{\circ} \mathrm{C}$. - The relaxations are different, when $T<100^{\circ} \mathrm{C}$ and $T>100^{\circ} \mathrm{C}$. 
3.1.1 «Maxwell Wagner » relaxations. - These relaxations depend on the sample : several activation energy can be found-for instance, with a SOREM sample, we obtain the $\operatorname{tg} \delta$ versus $\omega$ curves of figure 1 (curves I, II, III). The results were independent on

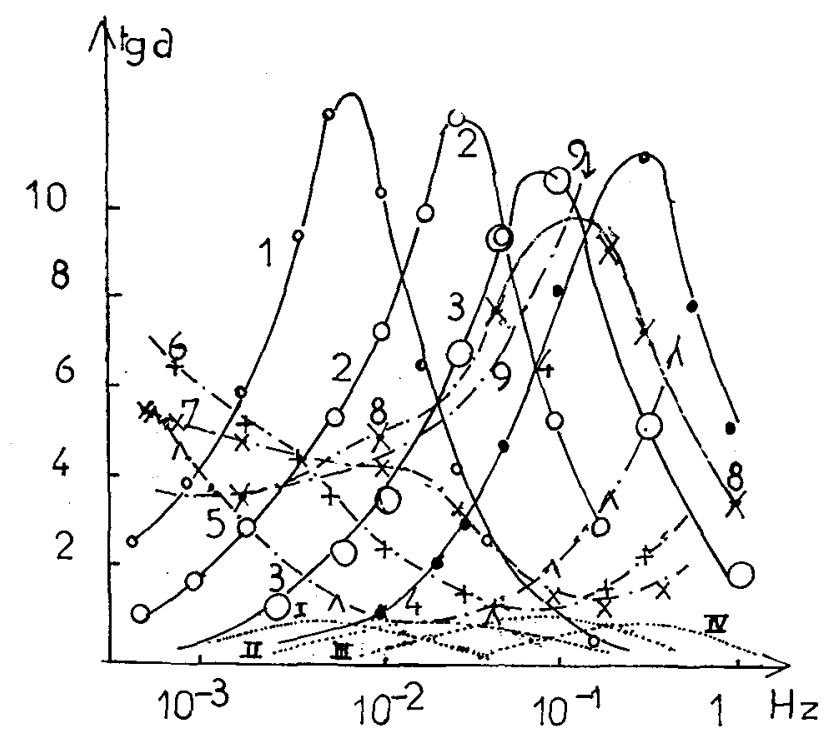

Fig. 1. $-\operatorname{tg} \partial$ versus frequency. ..... Low temperature range. $-\cdot-\cdot-\cdot$ - Middle temperature range. _- High temperature range. I, II, III, IV, $T=18,37,52$ and $60^{\circ} \mathrm{C}$. $1,2,3,4, T=166,204,258,310^{\circ} \mathrm{C} .5,6,7,8,9, T=339,541$, $560,588,615^{\circ} \mathrm{C}$.

contacts and on applied voltage, they don't change with a DC superimposed voltage. In potential distribution plots (Fig. $2 a$ ) we see that the bulk voltage of the sample is about $V_{0} / 2$, where $V_{0}$ is the applied voltage ; Chen and MacDonough [5], Tan and Kramp [6], found this relaxation with about the same activation energy $(0.55 \mathrm{eV})$. From these autors, these relaxations could be due to free vacancies or intersticials. Some SOREM crystals showed a $0.85 \mathrm{eV}$ relaxation with $\operatorname{tg} \delta \sim 1$-similar to a relaxation found by Jacobs [7]. These effects are ohmic and linear.

3.1.2 Schottky effect. - Above $100^{\circ} \mathrm{C}$ we found, in all the used crystals a relaxation with an activation energy near 1.25-1.3 eV. For instance, in Quartz and Silice crystals, this relaxation can be seen in the U. L. F. range, with $100^{\circ} \mathrm{C}<T<300^{\circ} \mathrm{C}$ (Fig. 1, curves 1, 2, 3 ) with a $\operatorname{tg} \delta_{\max } \sim 10$. (The loss tangent maximum is dependant on impurity concentration.) With a $0.1 \mathrm{~V}$ applied amplitude on the sample, the relaxation is of the Debye type, but with a DC superposed voltage, dispersion is lowered and behavior is disturbed. In the corresponding potential distribution curves (Fig. $2 b$ ) we see that the two electrodes no longer play the same part, the sample is more blocked near the cathode than near the anode. Even in high purity $\mathrm{CaF}_{2}$ samples, trace concentration of trivalent impurity ions can

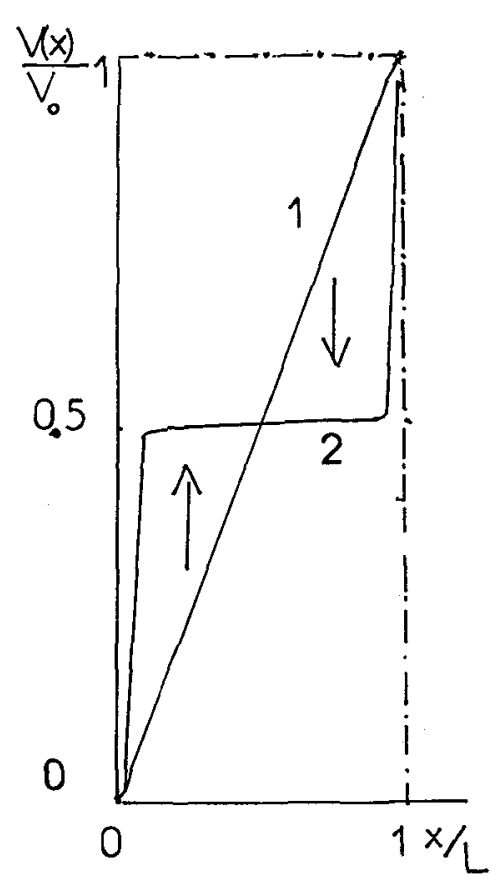

Fig. 2a. - First relaxation (room temperature).

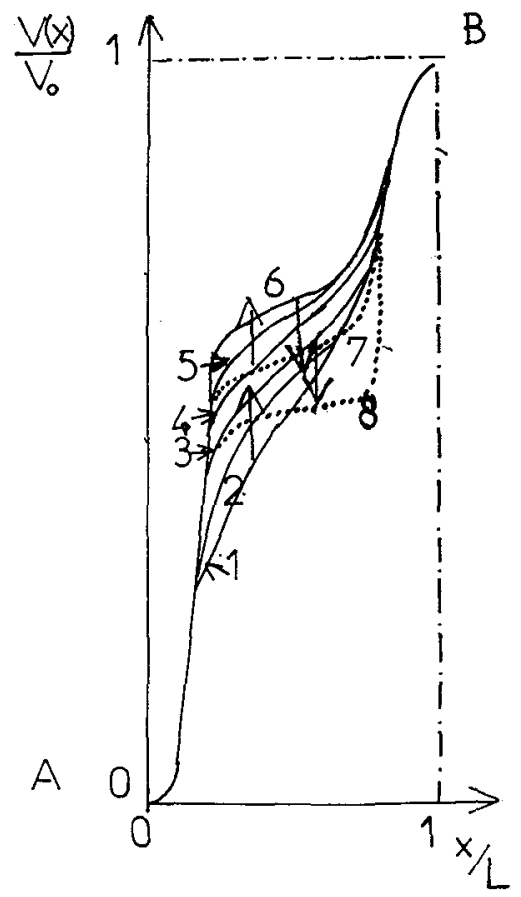

FIG. $2 b .-\uparrow$ First relaxation (Schottky). $\downarrow$ Second relaxation (Warburg) (1.5 V applied) ; $T=130^{\circ} \mathrm{C}$.

remain, they are charge compensated locally by fluorine ion interstitials. At low temperatures, this complex remains bound to form a local dipolar state, but at a sufficient high temperature, the compensating negative ions tend to dissociate from the trivalent ions ; and the relaxation always has the same activation energy - as 


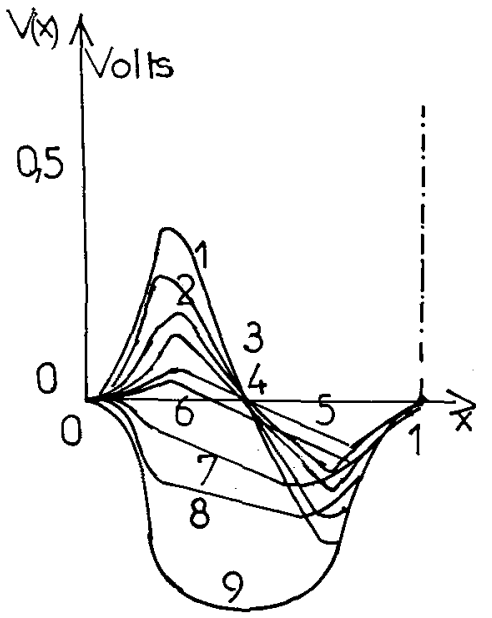

FIG. 2c. - (1), (2), (3), (4) 1rst relaxation. (5), (6), (7), (8), (9), Warburg. Relaxation, $T=130^{\circ}$.

in the electret behaviour [3]. This activation energy depends very weakly on the kind of impurity added to the crystal.

A depletion layer-already described in electret previous work [2] is built up near the cathode So a Schottky ionic barrier stands near the negative crystal surface, corresponding to the non linear behavior observed in the electret case.

Nevertheless, contacts are evaporated, and are closer than electret contacts, so the non linear behavior appears in AC measurements with a much lower DC voltage superimposed on the weak $A C$ voltage - than in the electret case.

In potential distribution curves, we can compare surface barriers with (Fig. $2 b$ ) and without (Fig. $2 c$ ) an external voltage. We can see that the surface barrier for contact B (direct polarization) is no much lower in figure $2 b$ than in $2 c$. So the outer voltage $V_{\mathrm{D}}$ is almost fully applied to contact $A$, where polarization is inverse. If $V_{\mathrm{B}}$ is the barrier height with no external voltage, then (with $1.5 \mathrm{~V}$, Fig. $2 b$ ) $V_{\mathrm{D}}>V_{\mathrm{B}}$. Although more experiments must yet be made, the AC capacitance with a superimposed DC voltage is a differential capacitance. So this capacitance varies mostly as $V_{\mathrm{D}}^{-3 / 2}$, when $V_{\mathrm{D}}$ is greater than $1.5 \mathrm{~V}$ as in a Schottky barrier.

3.2 High temperature Range. - In the high temperature range, we can see a very well defined Warburg phenomenon, with a maximum frequency $F_{\mathrm{D}}$ very little dependent on temperature, over a very large temperature range.

The equivalent Bauerle [8] circuit seems very convenient. $R_{2}$ (Fig. 3 ) is the bulk resistance of the sample, $Z_{\mathrm{W}}$ the Warburg impedance, $R_{1}$ a leakage resistance. The Bauerle circuit seems more convenient than the conventionnal Sluyter's one, because impedance is not infinite when frequency is lowered to zero. We shall see that (Fig. $4 c$ ) $R_{1}$ and $R_{2}$ are dependant on voltage and

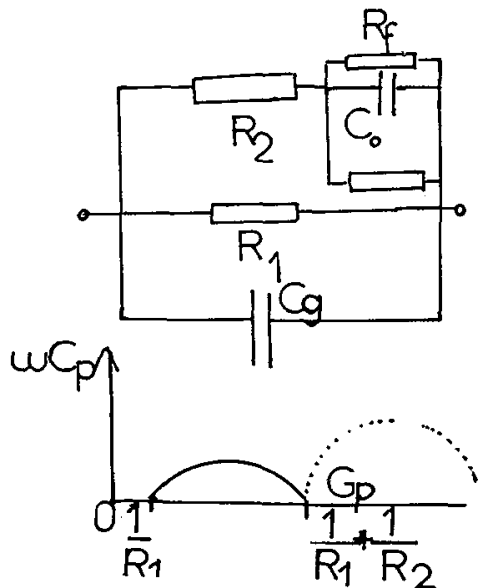

Fig. 3.

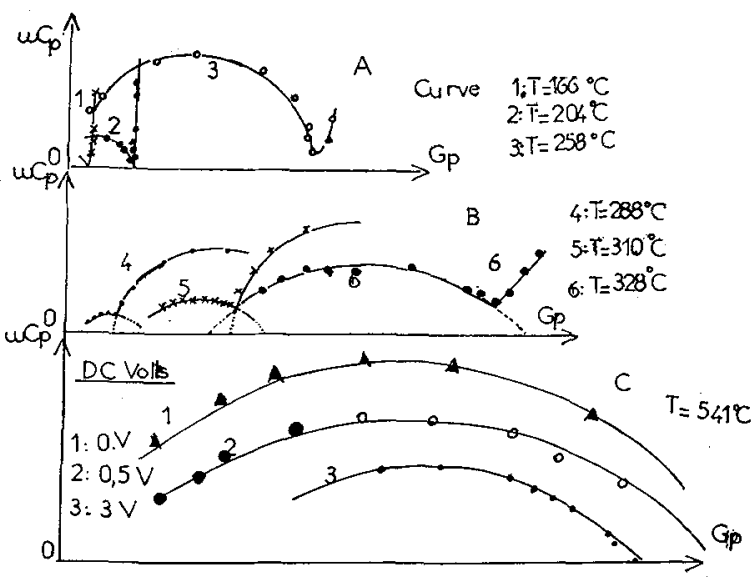

FIG. 4.

atmosphere : $R_{1}$ (as $\theta$ in a Sluyter's circuit) is lowered when voltage is raised, or $\mathrm{O}_{2}$ atmosphere introduced to the sample. $R_{2}$ is raised by an external voltage, but lowered by $\mathrm{O}_{2}$.

In a good vacuum, with no external $D C$ voltage, the experimental value are very easily reproduced. From Bauerle's equivalent circuit [8] we have

$$
2\left(\pi F_{\mathrm{D}}\right)^{1 / 2} A R_{2}=1
$$

and

$$
\begin{gathered}
Z_{\mathrm{W}}=A \omega^{-1 / 2}+j A \omega^{-1 / 2} \\
A=(2 D)^{1 / 2} \frac{e^{2} N_{0}}{K T}
\end{gathered}
$$

$D$ is the diffusion coefficient and $N_{0}$ the carrier density.

From $F_{D}$ we obtain $A$, and from $A$ and $R_{2}$ the density of intrinsic charges. But in the intrinsic range, Calcium Fluoride conductivity and carrier mobility were studied by numerous workers, some new numerical values were recently published [10]: 
We have

$$
\begin{aligned}
& \sigma T=9.9 \times 10^{8} \exp (-21820 / T) \Omega^{-1} \mathrm{~cm}^{-1} \mathrm{~K} \\
& \mu T=220 \exp (-5920 / T) \mathrm{cm}^{2} \mathrm{~K} / \mathrm{Vs} .
\end{aligned}
$$

From these formulas, we easily compute $N_{0}$ and $D$ and a comparison can be made with experimental data. Table I, we see a rather good agreement however the values from Warburg data are somewhat smaller than those from equation (4). The agreement is better with $\mathrm{Au}$ than with $\mathrm{C}$ electrodes.

Discussion. Conclusion. - Three chief conclusions can be made :

a) Dielectric measurements on electrolytic solid cells are quite possible, with imperfectly blocking contactsand imperfectly ohmic contacts. Lanyi [4] computed space charge effects and measured dielectric properties on a $\mathrm{Pt} \mathrm{NaCl} \mathrm{Pt}$ cell : he found that, even with these theoretically perfectly blocking contacts, a permanent current flows through the sample, when a direct low voltage is applied. So the requirements of O'Raleigh [9] seem too rigorous, because some adsorption effects are always effective, and so perfectly blocking contacts are not available.

In $\mathrm{CaF}_{2}$, the results are very reproducible, during several weeks and months, all the studied relaxations can be reproduced, and irreversible chemical reactions are very improbable, at least in $\mathrm{AC}$ measures when a good vacuum is used.

b) Nevertheless, surrounding atmosphere (and chiefly $\mathrm{O}_{2}$ ) plays a part by creating surface defects : irreversible outflow of Fluorine can result.

c) Space charge theories, with one kind of carriers partly blocked ; would give us (in the high temperature range, there is only one kind of mobile carriers in $\mathrm{CaF}_{2}$ ) a Debye relaxation [4]. But a complete theory is not yet available, surface effect, traps in the conduction band and band bending must be taken into account; in such a theory one can predict a Warburg effect through the surface barrier as the chief relaxation phenomenon.

\begin{tabular}{|c|c|c|c|c|c|c|c|c|c|c|}
\hline$T \mathrm{~K}$ & Electrode & $\Omega=2 \pi F_{\mathrm{d}}$ & $\begin{array}{l}R_{1} \\
\Omega\end{array}$ & $\stackrel{A}{A}$ & $\begin{array}{l}R_{2} \\
\Omega\end{array}$ & $\begin{array}{l}N_{0} \\
\mathrm{~m}^{3}\end{array}$ & $\begin{array}{l}N_{0}^{\prime} \\
\mathrm{m}^{3}\end{array}$ & $t=\varepsilon / \sigma$ & $M=\frac{L}{L_{\mathrm{D}}}$ & $\begin{array}{c}M t \\
R_{\mathrm{S}}\end{array}$ \\
\hline 561 & $\mathrm{Au}$ & $4.3 \times 10^{-2}$ & $1.3 \times 10^{9}$ & $7.6 \times 10^{-5}$ & $1.0 \times 10^{9}$ & $1.1 \times 10^{19}$ & $2.0 \times 10^{18}$ & $1.4 \times 10^{-2}$ & $1.6 \times 10^{3}$ & $2.2 \times 10$ \\
\hline 583 & $\mathrm{Au}$ & $4.3 \times 10^{-2}$ & $4.0 \times 10^{8}$ & $1.5 \times 10^{-4}$ & $2.1 \times 10^{8}$ & $1.7 \times 10^{19}$ & $4.0 \times 10^{18}$ & $3.6 \times 10^{-3}$ & $2.7 \times 10^{3}$ & 9.7 \\
\hline 601 & $\mathrm{Au}$ & $3.2 \times \overline{10^{-2}}$ & $2.2 \times 10^{8}$ & $5.0 \times 10^{-4}$ & $8.0 \times 10^{7}$ & $1.0 \times 10^{20}$ & $1.1 \times 10^{19}$ & $1.2 \times 10^{-3}$ & $4.1 \times 10^{3}$ & 4.9 \\
\hline 612 & $\mathrm{Au}$ & $3.2 \times 10^{-2}$ & $1.1 \times 10^{8}$ & $1.6 \times 10^{-3}$ & $3.0 \times 10^{7}$ & $4.0 \times 10^{20}$ & $3.1 \times 10^{19}$ & $6.4 \times 10^{-4}$ & $8.0 \times 10^{3}$ & 5.1 \\
\hline 683 & $\mathrm{Au}$ & $4.3 \times 10^{-2}$ & $1.2 \times 10^{7}$ & $4.6 \times 10^{-2}$ & $4.0 \times 10^{6}$ & $1.0 \times 10^{21}$ & $7.0 \times 10^{20}$ & $1.8 \times 10^{-5}$ & $1.2 \times 10^{4}$ & $2.1 \times 10^{-1}$ \\
\hline 703 & $\mathrm{C}$ & $6.3 \times 10^{-2}$ & $1.0 \times 10^{7}$ & $1.5 \times 10^{-2}$ & $1.0 \times 10^{6}$ & $5.0 \times 10^{21}$ & $2.0 \times 10^{20}$ & $7.0 \times 10^{-6}$ & $3.0 \times 10^{4}$ & $2.1 \times 10^{-1}$ \\
\hline 753 & $\mathrm{C}$ & $4.3 \times 10^{-1}$ & $5.0 \times 10^{6}$ & $7.0 \times 10^{-2}$ & $1.9 \times 10^{5}$ & $2.5 \times 10^{22}$ & $7.5 \times 10^{20}$ & $9.0 \times 10^{-7}$ & $5.8 \times 10^{4}$ & $5.2 \times 10^{-2}$ \\
\hline 812 & $\mathrm{C}$ & $6.3 \times 10^{-1}$ & $1.0 \times 10^{6}$ & $5.0 \times 10^{-1}$ & $7.0 \times 10^{4}$ & $1.6 \times 10^{23}$ & $9.3 \times 10^{20}$ & $1,3 \times 10^{-7}$ & $1.4 \times 10^{5}$ & $4.9 \times 10^{-2}$ \\
\hline 888 & $\mathrm{C}$ & $3.1 \times 10^{0}$ & $3.1 \times 10^{4}$ & $1.1 \times 10^{-0}$ & $3.3 \times 10^{3}$ & $8.0 \times 10^{23}$ & $6.0 \times 10^{21}$ & $1.5 \times 10^{-8}$ & $3.0 \times 10^{5}$ & $4.5 \times 10^{-3}$ \\
\hline
\end{tabular}

\section{TABLE I}

\section{References}

[1] Levitskir, V., Hammou, A., Duclot, M., Desportes, C., J. Chim. Phys. 73 (1976) 305.

[2] Lacabanne, C., Chatain, D., Madru, R., Maitrot, M., J. Chim. Phys. 71 (1974) 597.

[3] Podgorsak, E. B., Moran, P. R., Phys. Rev. B 8 (1976) 3405.

[4] Chen, J. H., McDonough, Bull. Amer. Phys. Soc. 11 (1966) 195.
[5] LanYI, S., J. Phys. \& Chem. Solids 36 (1975) 775.

[6] Tan, Y. T., Kramp, D., J. Chem. Phys. 53 (1970) 3691.

[7] J JCOBS, G., J. Chem. Phys. 27 (1957) 1441.

[8] Bauerle, J. E., J. Chem. \& Phys. Solids 30 (1969) 2657.

[9] O'Raleigh, D., Phys. Status Solidi a 4 (1971) 215 and Electroanalytical Chem. 6 (1973) 87.

[10] Bollman, W., Henniger, H., Phys. Status Solidi a 11 (1972) 367. 